\title{
Nord Stream and South Stream as innovative projects, their impact on the energy sector environment and policies of the European Union
}

\section{Introduction}

The energy sector is rightly considerate as one of the basic industries and has been divided into four basic sub-sectors: energy, gas, heat, liquid fuels and mining, which is sometimes classified as electricity (Dobroczyńska, Juchniewicz, Zaleski, 2001, p. 39), Belonging to one of the identified sub-sectors depends on the raw material on the basis of which it is conducted business activity, and hence gas industry is a sub and as the name suggests activity is associated with the gas (Elżanowski, 2008, p. 27).

Natural gas is one of the primary energy in the EU. It is one of the relatively inexpensive, and fairly available organic primary energy, since the combustion gas is formed about half the carbon dioxide (greenhouse gas) compared to oil or coal.

Currently, the leading position in the global trading system of oil and gas takes Russia. The country is also in the forefront of exporters of primary energy sources. Russia has more than $20 \%$ of global gas reserves and $5 \%$ of proven oil for example only one Russian company "Газпром" brings $15 \%$ of world gas production. OAO "Газпром" is a powerful Russian energy concern with complex technology, which has a unique structure. The consistent system of "Газпром" is one of the largest in the world gas supply systems and combines objects of extraction, processing, transportation, storage and distribution of gas. The single delivery system creates and guarantee an uninterrupted cycle, that is - from the well to the end user. The uniform system of gas pipeline "Газпром" has 155 thousand km of main gas pipelines and branches, 6 complexes for working gas and liquefied natural gas, 24 natural gas storage facilities and the numbers are still growing. OAO "Газпром" is a leading supplier of energy resources including natural gas to the European Union.

According to experts and analysts, regardless of the decline in gas consumption in Europe (a decrease of about 7\%) in the past few years, the demand for this product will get higher in the European Union and all around the world (Коржубаев, Федотович, 2010 , p. 4-6). It is expected that by 2030 demand for natural gas will be about 4831 billion $\mathrm{m}^{3}$, which would constitute about $25 \%$ of global energy consumption initially. According to expert forecasts demand for natural gas in Europe by 2030 will rise to 210 billion $\mathrm{m}^{3}$ per year or 50\% (Rychlicki, Siemek, 2008, p. 410-412). Significant also is the fact that the share of natural gas in the so-called structure of primary energy consumption across the EU varies. For example, in Greece and in Portugal of about $8 \%$ and $14 \%$, and $38 \%$ - Italy and the UK - 36\% (BP, 2009). For EU countries with a high per- 
centage of natural gas consumption verification suppliers and transmission system plays a blue fuel being role. And it should be noted that the so-called the "old" Member States have a higher degree of diversification their sources of supply of blue fuel percentage: from Russia comes around $-30 \%,-30 \%$ from Norway and Algeria $-18 \%$ (Łoskot-Strachota, 2009, p. 2-4).

Table 1

Natural gas in Europe-34-production and import demand

\begin{tabular}{||l|c|c|c|c||}
\hline \multicolumn{1}{|c|}{ mld m$^{\mathbf{3}} / \mathbf{y e a r}$} & $\mathbf{2 0 0 0}$ & $\mathbf{2 0 1 0}$ & $\mathbf{2 0 2 0}$ & $\mathbf{2 0 3 0}$ \\
\hline Own Extraction & 262 & 266 & 202 & 163 \\
\hline Demand (reference scenario) & 482 & 650 & 767 & 815 \\
Imports (reference scenario) & 221 & 385 & 565 & 625 \\
\hline Demand (low scenario) & 482 & 570 & 595 & 635 \\
Imports (low scenario) & 221 & 304 & 393 & 472 \\
\hline
\end{tabular}

In Table 1 is shown the potential of gas exports to 34 European countries Europe-34 EU-27 countries also Switzerland and Balkan countries.

Source: S. Rychlicki, J. Siemek (2008), Gaz ziemny w polityce energetycznej Polski i Unii, Europejskiej, "Polityka energetyczna”, t. II, vol. 1, Krakov, p. 412.

The implementation of large infrastructure projects is closely linked to the protection of the environment, and the existing EU legal standards in this area are very strict. Projects that can show a negative impact on the balance of the environment undergo a comprehensive examination on the basis of which the relevant EU institutions issue licenses for their projects. According to EU law investment monitoring of such objects must be continuous.

The article analyzed energy projects Nord Stream and South Stream in terms of security in this environment, the effectiveness taken by investors pollution prevention measures, as well as the role of designated projects in the energy security of the European Union and the diversification of suppliers of natural gas to the EU. Article analyze the important aspects of political issues related to the investment of the Russian "Гa3пром" in Europe.

The primary goal of this article is to analyze the impact of projects Nord Stream and South Stream energy sector environment. And also the political aspects associated with the implementation of these energy projects.

\section{The origin and status of the North European Gas Pipeline (Nord Stream)}

After the hot disputes about gas between politicians of Ukraine, Belarus and Russia in the late 90's and 2000's, when European customers more than once severely affected on a shortage of gas, and the reputation of the Russian "Газпром" has been seriously tarnished. Management of the group "Газпром" has taken a final decision on the construction of a gas pipeline North (Nord Stream), and in the future further expansion of direct transmission network to Europe in the implementation of the South Stream pipeline project (South Stream). The primary objective of the project was the construction 
of the Nord Stream gas pipeline bypassing intermediate transit countries, inter alia, Ukraine, Polish, Slovak and Czech Republic, and to provide Member of Western Europe, in the first turn Germany guaranteed supply of natural gas (Kubik, 2007).

Uniqueness of the Nord Stream project lies in the fact that, the pipeline runs through the economic zones of many countries like: Russia, Finland, Sweden, Denmark, Polish, and the Baltic Sea, also provides a direct link between Russian and European gas pipeline systems (type "from the wellbore to the receiver"). The total length of the Nord Stream - $1224 \mathrm{~km}$ from Russian Vyborg to the German Lubmin near Greifswald, where gas will be transported to Belgium, Denmark, France and Great Britain.

In September 2002, during the visit of Russian President Vladimir Putin in Germany signed an agreement for the construction of the Nord Stream. The company - contractor of the project "North European Gas Pipeline Company" was founded in 2005, but in 2006 the name was changed to Nord Stream AG. The shareholders of the newly established company are: OJSC "Gazprom", the German BASF AG and E.ON AG, and the president of the company's shareholders - Gerhard Schröder (https://www.nord-stream.com/pl/o-nas/nasi-udzialowcy/). All permits necessary to start construction work of the Nord Stream received in February 2010, Nord Stream is considered to be one of the most expensive projects implemented so far by "Газпром". It was estimated that the Russian company has to spend on project Nord Stream no less than 750 million euros. The total cost of the project estimated at 8.8 billion, but all indications are that this figure will be higher (Онуфриева, 2011, p. 70-71).

Labor Project started already in the first decade of the 2000's, however, vigorously construction of a pipeline started only in 2010, when at the ceremony were set tubes of the first strand of the Nord Stream. Construction of the second thread started in May 2011, and in October 2012 was put into service. Opening of the first strand of the Nord Stream was held with the participation of Russian President Dmitri Medvedev and Chancellor Angela Merkel.

Nord Stream is an international project. Process prior to its launch lasted a relatively long time, because it was necessary to obtain the required permits for the construction of five countries. Also, it was necessary to assess and examine all aspects in terms of regulations, contained in international conventions and acts of national law. In 2006, under the provisions of the European Commission, the Nord Stream project finally received the status of the energy of the highest priority in the European Union. Which means that Nord Stream has been recognized as part of the trans-European energy networks (Trans-European Energy Networks TEN-E) and bears the nature of the investment strategy of the European Union providing a stable supply of natural gas and a good example of cooperation between Russia and the EU (Plajtgen, 2011).

The international character of the Nord Stream also provides that for its realization were recruited experts from 17 countries and the European top advisers in the field of environmental protection. Another endorsement of the European nature of the project is the structure of the performers. In terms of environmental impact assessment and for special permission selected Danish company Rambøll, and the range of engineering services - the Italian company Saipem Energy Services (Snamprogetti). Certification of the project was commissioned independent foundation Det Norske Veritas (DNV), headquartered in Oslo. The Swedish company Marin Mätteknik AB (MMT) has conduc- 
ted research for the presence of munitions along the planned route of the pipeline. Other studies of environmental and field tests are conducted by well-known international companies, such as the Swedish Geological Survey (SGU), PeterGaz (Russia), Finnish Institute of Marine Research, DHI (Denmark), Fugro OSAE (Germany) and the Institute for Applied Ecology (Germany). 75\% of pipes for the construction of the first pipeline will provide the German company Europipe, and the remaining 25\% - the Russian company United Metallurgical Company (OMK). In terms of the pipelaying signed a preliminary agreement with the company Saipem, based in London (http://www.nord-stream.com/pl).

\section{Threads of political and economic rationalism}

The construction of the future pipeline preceded by a tedious and uneasy process of international discussions and consultations with interested countries. Not all countries at once consented. And investors Nord Stream had a difficult nut to crack. Besides information about the plans to build a new gas pipeline caused concern and dissatisfaction not only for the local authorities of Ukraine and Belarus, but as well as Polish, Czech and Slovakia. The most important allegations made by these countries are the following: first, the gas monopoly position that Russia threatens the energy security of the European Union, and secondly, Russia can manipulate decision-making processes in some of these countries (talking about Ukraine and Belarus), or exert pressure on them by the method called "screwing tap". Of course, the countries of the EU can count on the support of the EU. Unfortunately, Ukraine, which was often accused by the Russian "Газпром" in unsatisfying receiving gas will probably need to activate their own action towards diversification of gas supplies (Итоговая пресс-конференция..., 29 июня 2012 года). The decisions in Ukraine should also more strongly determine the direction of further development of the country, keeping in mind that the choice of pro-European direction, requires compliance with European standards, as in politics and economics. In a situation where the ruling authority Ukraine chooses variant tightening cooperation with Russia, can automatically expose their country to limit the independence and sovereignty.

It seems, however, skeptical attitude of some countries in relation to the Nord Stream project and the unsuccessful attempts to block it was rather an economic one. Because the undeniable fact is that the countries that run networks, and will reap the profits from the transit of Russian gas. The route of the new pipeline bypasses their territory, which automatically deprives the state specified above large share of payments for gas transit. This situation was caused by technical changes made in the course of the investment. Originally it was assumed that the raw material for filling the new pipeline will come from the North Stockholm's deposit, but due to delay in the preparation of the infrastructure to extract gas from the fluidized, part of the gas transported so far by Poland, Ukraine, Czech Republic and Slovakia will supply the Nord Stream (www.gazprom.ru).

After reviewing the plans and medium-term strategy of "Газпром" can be concluded that the operation of the bed and start Stockholm's Nord Stream gas pipeline, and so 
will the quantitative reduction of gas transported via gas pipeline system hitherto used by Ukraine, Poland, Czech Republic, Slovakia. Indeed, OAO "Газпром" pursues its objective, which is to eliminate as many countries of transit, which reduces the cost of exports (it counts the management of OAO "Газпром") of natural gas from Russia.

\section{The issue of environmental protection and safety}

You can not ignore the issue of environmental protection of the Baltic Sea and its waterfront. The specific issues particularly related to the Baltic countries (Estonia, Lithuania, Latvia, Finland and Poland). The initial project investment assumed to connect gas systems of the Baltic states, including Latvia and the use of storage capacity for the collection and storage of gas. Then none of the countries has objected, also in terms of environmental safety. Eventually it was decided to change the route of the Nord Stream. Adopted final pipeline plan did not foresee any branch or call the gas systems of the Baltic States (talking about Estonia, Lithuania, Latvia and Poland). In response to the report indicated solution was made by experts from the Estonian Academy of Sciences (Prof. Mihkel Veiderma and prof. Dr. Endel Lippmaa), who expressed extremely negative view of the construction of the Nord Stream justifying its position as follows: - no entity responsible for possible failures and disasters that may occur during construction and operation of the pipeline.

The pipeline remains in close contact with the sea zone Estonian, this gives rise to the appearance on the borders of Estonia, the Russian naval patrols.

In addition, the scientists in Estonia were worried by the lack of information on safety (the remains of the Second World War on the seabed, the instability of the ground) of new pipeline route in the North, also doubt has undergone technical execution (Veiderma, 2005; Lippman, 2007).

Arguments of researchers from the Estonian Academy of Sciences are not too convincing. And it's hard to say how much the policy, and how economic rationalism and pragmatism in this? Firstly, it is difficult to imagine a Russian naval military patrols in the waters around the territory of the member states of NATO. Secondly, investors are aware of the dangers that entails ammunition and war gases, which remains after the Second World War at the bottom of the Baltic Sea. Sea pipeline route will be thoroughly examined, and the items that will be a source of potential danger removed. As for the technical execution, in the realization of the Nord Stream will participate Italian company Saipem, which has years of experience and have already implemented similar projects in the Black Sea (Blue Stream to Turkey), there were no complications and perturbations. Finally, there is a positive official of the European Commission, which in my opinion ultimately end the dispute on the merits of the pipeline Nord Stream.

In April 2013, the Baltic Sea Forum in Saint-Petersburg Prime Minister of the Russian Federation Dmitry Medvedev in his speech to the participants pointed out that as a result of carried out in 2012, the marine ecological monitoring section of the Russian section of the Nord Stream pipeline. It was agreed that the work of the pipeline does not adversely affect the environment of the Baltic Sea. Leading experts of "Газпром" in reading the official results of the monitoring and unambiguously confirmed the neutrality 
of the pipeline on the environment circumferential (Отчёт по экологическому мониторингу морского участка российской секиии газопровода Nord Stream... за 2012 год).

In Poland, until now there is ongoing political discussions about the Nord Stream project, but the pipeline is already finished. Poland has had a lot of concerns about the future of the Port of Swinoujscie, which is under construction LNG (liquefied gas).

The future of the port of Swinoujscie very well said by Minister of Foreign Affairs Sikorski: "Everything so far going in Swinoujscie will still be shipped in and gas tankers to the Polish LNG terminal that is already built, will be shipped in unhindered."

"There will be no obstacles, because" - as explained - "we received a recess for more than 20 kilometers, which will cause gas carriers will flow to the gas terminal on the main along the approach." "In contrast to the spare tube moved to deeper water, plus the assurance that if in the future the port wanted to continue to develop, need to take even larger vessels, the tube there is a recessed" (PAP, 2011).

According to W. Pawlak commenting on the completion of the first line. - We will focus on elements that relate to our security, not the frustration about what others are doing (Lakoma, 2011).

\section{Warranty and liability on the part of the implementers of energy projects}

Prior to the commencement of construction works meticulously examined the impact of the pipeline on the possible threat to the environment.

According to Nord Stream AG to ensure safe operation of the pipeline located at the bottom of the Baltic Sea, Nord Stream AG by independent companies from Sweden, Russia, Germany, Norway, Finland and Denmark (detailed technical documentation prepared by a leading energy company Saipem Energy Services, formerly Snamprogetti, Italy) carried out a large number of research and has invested over 100 million euros (Kompleksowe badania zgodności ekologicznej). The study covered a wide range of issues: geological, environmental, biological, socio-economic environment, which include fisheries, shipping and navigation, tourism and recreation, industry and the military actions, etc (Gaz ziemny: istotny element dywersyfikacji źródet energii).

Also international research teams working on the Nord Stream project in the field of environmental safety have provided a comprehensive program of environmental monitoring of the Baltic Sea. On the basis of the above program is planned that will run continuously monitoring and Nord Stream AG plans to spend for this purpose more than 40 million. The results of ecological monitoring should be available to all competent authorities in the Baltic States and stakeholders. According to the specially worked out a comprehensive program to protect the unique natural environment, the new pipeline should not only comply with all the modern rules of safety and environmental protection, as well as regularly undergo cleaning and maintenance. Technical Service of Northern pipeline consists of external and internal control.

The first scheduled maintenance of the internal control and using innovative technology will be carried out during the summer of 2013. To this end, in the middle of a gas pipeline from the Gulf of Finland will be allowed diagnostic charges. They are suppo- 
sed to check the condition of the pipes. Then they run a special device that will collect dust and dirt inside the pipeline and allow the final phase of checks carried out full-range of technical research (Хренников, 2012, p. 6-9).

External inspection of the pipeline will be carried out by specially equipped for this purpose the ship, on board of which will be modern equipment including cameras and sophisticated high technology equipment designed to work under water. With them will be controlled condition of the seabed of the Baltic gas pipeline system. After completion of the study all the information will be analyzed in terms of the potential risks arising from changes in operation of the pipeline. Nord Stream AG takes full responsibility for the safety and condition of the North European Gas Pipeline, and I guarantee control and repair all damages incurred during his work (Kim jesteśmy).

\section{The investment planned South Stream}

September 16, 2011 at the Investment Forum in Sochi companies "Gazprom", the Italian ENI, French EDF and German Wintershall (BASF) have concluded an agreement on the appointment of the life of the company South Stream Transport (SST). According to the agreement, the company will be the legal owner of SST 900 -kilometer stretch of sea South Stream gas pipeline (Porozumienie udziałowców gazociagu SouthStream).

The investors' participation in the South Stream [\%]

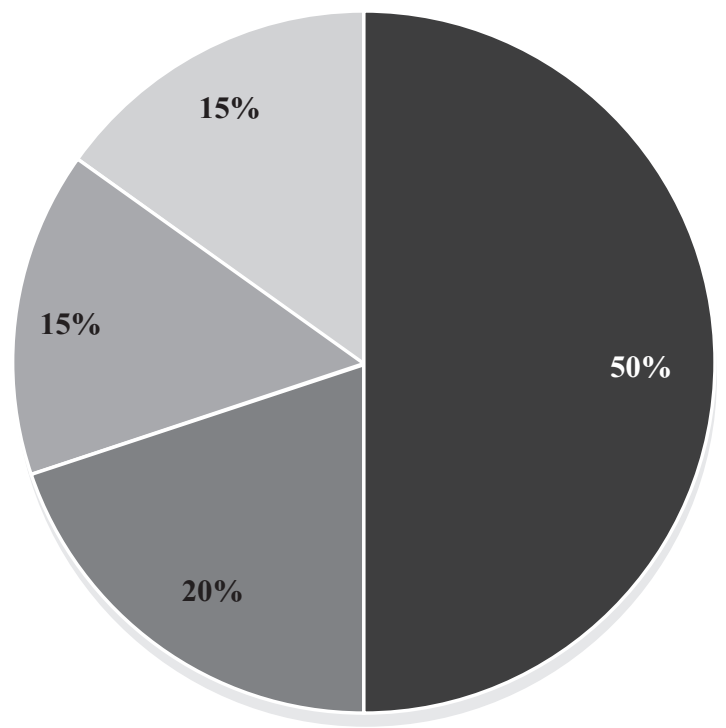

\begin{tabular}{|c|}
\hline $50 \%$ OAO "Газпром" \\
(Russia) \\
20\% Eni S.p.A \\
(Italy) \\
$15 \%$ EDF \\
(France) \\
15\% Wintershall \\
Holding GmbH \\
(Germany BASH Group)
\end{tabular}

The half-day pipeline (South Stream) is designed to deliver natural gas from Russia through the Black Sea and the Balkans to Central Europe and South America. First nothing pipeline should be launched in 2015, and the completion of all construction-in 2018 (Porozumienie udziałowców...). 
It is planned that the power of the South Stream pipeline will be increased gradually, eventually has to reach $-63 \mathrm{mld} \mathrm{m}^{3}$ year. And the first pipeline will be launched at the end of 2015. The project can be conventionally divided into two parts: the first, as already mentioned, is to build a gas via the Black Sea, the second-creation of a new gas network in Southern and Central Europe. In addition to this it will be necessary expansion and modernization of the gas pipeline on the territory of Russia. Length of the sea estimated at $900 \mathrm{~km}$ and the planned rise here four branches (thread), the maximum depth of the pipe-laying work of the future pipeline is 2,250 meters.

Part of the honor of the future gas pipeline through the territory of Bulgaria, Serbia, Slovenia, Hungarian Italy. From the basic branches of the pipeline will be discharged to the Croatian and Serbian Republic, project is still in planning phase. The initial project value is around 15.5 billion euros (http://www.gazprom.ru/about/production/projects/pipelines/south-stream/).

OAO "Газпром" ensures that SOUCHE Stream project will be done in compliance with all the requirements of environmental safety, in accordance with the Espoo Convention.

The project is highly controversial. Controversy cause the following issues, which have the character of political and economic. The most important of them:

- Is the implementation of the investment does not interfere with the creation of a common EU energy policy?

- South Stream does not threaten the energy security of the EU?

- Does the project is not directed against the autonomy and independence of Ukraine? Due to the global crisis, the risk of forecasting the development of global markets is significantly increased, and hence: it is impossible to accurately predict not only the dynamics of the demand for gas, but also to determine the price for a specified resource. Therefore raises the basic question - Is gas demand will grow but at a pace that the construction and operation of the South Stream will be economically viable? Work on the project continues. It seems, however, that the Nord Stream pipeline project is likely to be achieved to a limited extent.

For potential shareholders South Stream it is essential that the European Commission is working on the new regulations, the operation of the EU energy market. Under the new rules, investors pipeline must provide access to the infrastructure to other operators and putting it under the control of an independent operator. Do investors of the South Stream agree to new EU regulations, especially the Russian "Газпром", as the main shareholder and the initiator of the South Stream project? The talks with the competent authorities in the energy sector (national regulators) of each country through the territory of which will run the new pipeline. National regulator must inform the European Commission or agree to give the so-called status off. Even so, the last word in this regard belongs to the European Commission (Григорьев, 2008).

\section{Conclusions}

The energy sector is the foundation for national economies. The competitiveness of the economy depends largely on energy costs. The desire of the EU countries is to 
reduce energy costs and reduce greenhouse gas emissions, the increased use of energy from renewable sources and to prevent potential degradation and pollution of the environment in connection with exploration and exploitation of energy resources extracted.

In the coming decades, natural gas continues to remain one of the basic raw materials used in the European power industry. As a result the increase in gas consumption in Europe, because of ecological barriers and growing number of energy companies declaring their intention to build new power plants of natural gas can be regarded as inevitable.

Profitability of investments in gas energy will depend on the price of $\mathrm{CO}_{2}$ allowances and gas prices relative to electricity prices. And as indicated by the trend of natural gas prices falling and rising energy prices. Ultimately, the price of energy should oscillate at a level to ensure the competitiveness of the European economy.

Probably the leading importers of natural gas will remain Germany, Italy, France. Same countries that took part in Nord Stream and South Stream projects. Northern Pipeline regardless of discontent and concern on the part of some countries works and supplies natural gas to the European Union has been recognized by the European Commission as a priority. According to the monitoring of the environment of the Nord Stream gas pipeline was deemed compliant with all required European standards of environmental safety. As indicated by the results of ecological monitoring presented at the Conference in St. Petersburg Without any doubts, the pipeline project is an example of international cooperation, because it involved companies, researchers, experts from many countries.

Poland lost the opportunity to participate in the Nord Stream project. Worth recalling that Poland led active discussions on potential participation in the construction of the Nord Stream with the Russian side which never happened. Was it the right decision, will see in the future.

By specifying the South Stream project, according to its investors - is another step on the road to diversification of natural gas transmission networks in Europe. In view of the projected increase in demand for blue fuel by European countries South Stream could become one of the real ways to solve the problem of energy deficit and maintaining the Union's energy security.

The increasing number of new energy projects with the participation of Western companies shows that Russia is becoming more open to Western investment, especially in such sensitive sectors for her energy and fuel. The implementation of high-tech projects forces the concerns of Russian investments in the modernization and expansion of its transmission system, which has long been in need. As experts note, the Nord Stream pipeline and the planned South Stream, is not only an economic investments. These projects play an important role in the energy security of the European Union, because it provides natural gas directly to customers bypassing transit countries. For Russia, this new potential markets in Europe.

The expansion of the transmission network should reduce not only the prices of natural gas, as well as a positive impact on energy costs. Which in total will promote the competitiveness of the EU economy. Construction of modern transmission systems stimulates the development of economic and scientific. There are new technologies, new 
materials, modern tools and equipment. Construction and operation of new gas pipeline systems affect the growth of employment and promotes the formation of new jobs not only in the use of gas pipelines, as well as in other industries.

\section{References}

BP (2009), BP Statistical Review of World Energy, June 2009, www.bp.com, 12.03.2013.

Хренников Н. (2012), Nord Stream гарантирует!, “Газпром”, October 2012.

Dobroczyńska A., Juchniewicz L., Zaleski B. (2001), Regulacja energetyki w Polsce, Torun.

Elżanowski F. (2008), Polityka energetyczna. Prawne instrumenty realizacji, Lexis Nexis, Warsaw.

Gaz ziemny: istotny element dywersyfikacji źródet energii, https://www.nord-stream.com/pl/srodowisko/gaz-ziemny/, 10.03.20013.

Григорьев А. (2008), Много потоков хороших и разных:голубых, северных и южных с тем, что принесет России сооружение еще одной трубопроводной системы, ясности нет, "Мировая энергетика", vol. 8 (64), Moskow.

https://www.nord-stream.com/pl/srodowisko/gaz-ziemny/, 10.03.2013.

http://russian.rt.com/inotv/2011-11-09/Severnij-potok-ostavil-Ukrainu-i, 16.03.2013.

http://www.nord-stream.com/pl/o-nas/nasza-odpowiedzialnosc/, 26.03.2013.

http://www.osw.waw.pl/pl/publikacje/tydzien-na-wschodzie/2011-09-21/porozumienie-udzialowcow-gazociagu-south-stream, 26.03.2013.

http://www.ekonomia24.pl/artykul/654205-Polska-wciaz-liczy-na-zaglebienie-gazociagu-Nord-Stream.html, 1.04.2013.

http://www.nord-stream.com/pl/srodowisko/badania/, 1.04.2013.

http://www.gazprom.ru/about/production/projects/pipelines/south-stream/, 7.04.2013.

http://www.gazprom.ru/f/posts/00/320758/final-pressconference-stenogram-2012-06-29-rus.pdf, 19.04.2013.

Informacje o gazociagu, Nord Srea, chap. 2, p. 24-25, http://www.nord-stream.com/pl, 14.02.2013.

Итоговая пресс-конференция с участием Председателя Совета директоров и Председателя Правления ОАО «Газпром» 29 июня 2012 года, http://www.gazprom.ru/f/posts/00/320758/ final-pressconference-stenogram-2012-06-29-rus.pdf, 19.04.2013.

Kaliski M., Nagy S. (2010), Gaz ziemny w Polsce - wydobycie, zużcie i import do 2030 roku, "Górnictwo i geologia", Gliwice.

Kim jesteśmy, Nasza odpowiedzialność, Monitoring dostarcza istotne dane dotyczace środowiska, http://www.nord-stream.com/pl/srodowisko/badania/ and http://www.nord-stream.com/pl/ o-nas/nasza-odpowiedzialnosc/, 16.03.2013.

Коржубаев А., Федотович Б. (2010), Финансово-экономический кризис 2008-2010 годов и нефтегазовый комплекс России, “Проблемы экономики и управления нефтегазовым комплексом", Issue 9, Moscow.

Kompleksowe badania zgodności ekologicznej, http://www.nordstream.com/pl/srodowisko/badania/, 1.04.2013.

Kubik A. (2007), Gazprom - pasmo sukcesów 2006 rok, "Gazeta Wyborcza”, 7 January. 
Lippmaa E. (2007), Expert Opinion of the Academy of Sciences on the application submitted by the Nord Stream AG for granting permission to conduct pipeline route investigations in Estonian Waters as defined in unclos, Tallin.

Łakoma A. (2011), Polska wciaż liczy na zagłębienie gazociagu Nord Stream, http://ekonomia.rp.pl/ artykul/654205-Polska-wciaz-liczy-na-zaglebienie-gazociagu-Nord-Stream.html, 1.04.2013.

Łoskot-Strachota A. (2009), Ekspansja Gazpromu w UE - kooperacja czy dominacja, OSW im. Marka Karpia, Warsaw.

Онуфриева О. (2011), Инвестиционная сторона международных фазовых проектов, "Проблемы современной экономики", vol. 3, Saint Petersburg.

Отчёт по экологическому мониторингу морского участка российской секциигазопровода Nord Streamв соответствии стребованиями Минприроды России за 2012 год, http://www.mnr.gov.ru/activities/detail.php?ID=130041, 10.03.2013.

PAP (2011), Gazociag Pótnocny nie zakłóci dostaw gazu, http://gazownictwo.wnp.pl/sikorski-gazociag-polnocny-nie-zakloci-dostaw-gazu-do-polski,150048_1_0_0.html, 10.03.2013.

Plajtgen F. (2011), «Северный поток» оставил Украину и Польшу один на один с Россией, http://inosmi.ru/world/20111110/177393448.html?id=177406560, and http://russian.rt.com/ inotv/2011-11-09/Severnij-potok-ostavil-Ukrainu-i, 12.04.2013.

Porozumienie udziałowców gazociagu South Stream, http://www.osw.waw.pl/pl/publikacje/ tydzien-na-wschodzie/2011-09-21/porozumienie-udzialowcow-gazociagu-south-stream, 26.03.2013.

Rychlicki S., Siemek J. (2008), Gaz ziemny w polityce energetycznej Polski i Unii Europejskiej, "Polityka energetyczna", t. II, vol. 1, Krakov.

Veiderma M. (2005), Natural Gas in the Baltic Sea Region, Paper delivered at the session of Assembly of the Baltic States on 26 November 2005, http://www.akadeemia.ee/_repository/File/Veiderma_ettekanneINGL.pdf, 10.03.2013.

\section{Summary}

Natural gas is an indispensable resource in many industries. Its share in the primary energy consumption is relatively high, both in the European Union and globally. Energy security is a priority for each country, making the diversification of suppliers, energy sources and the construction of energy transmission systems come first in its implementation of energy policy goals. The paper discusses the following issues:

- the growing demand for gas in the European Union and its consumption forecasts. Energy security - diversification of gas suppliers and transmission systems. Innovative projects Severnyi Potok (Nord Stream) and Yuzhny Potok (South Stream). Political controversies and economic reality. The analysis of media rhetoric on this topic;

- do Nord Stream and Yuzhny Potok (South Stream) pose a threat to the energy security of the European Union, or are they strategically important projects, ensuring the stable and secure supplies of natural gas to EU countries? Environmental protection and the Nord Stream and South Stream pipelines. Economic cooperation between European and Russian companies in the implementation of the above projects.

Key words: natural gas, Nord Stream, South Stream, Russia, European Union, innovation, environmental protection, energy security, European Union 


\section{Innowacyjne projekty Nord Stream i South Stream. Ich wplyw na sektor energetyczny, środowisko naturalne i klimat polityczny Unii Europejskiej}

\section{Streszczenie}

Gaz ziemny jest niezbędny w wielu gałęziach przemysłu. Udział gazu ziemnego w strukturze zużycia tak zwanej energii pierwotnej pozostaje na dosyć wysokim poziomie, jak w Unii Europejskiej, tak i w Świecie. Każde państwo uważa swoje bezpieczeństwo energetyczne za sprawę priorytetową, a realizując założone cele w polityce energetycznej na pierwsze miejsce stawia dywersyfikację dostawców, surowców energetycznych i budowę systemów przesyłowych dla nich. W artykule poruszono następujące kwestie:

- rosnące zapotrzebowanie na gaz w Unii Europejskiej i prognozy jego zużycia; bezpieczeństwo energetyczne - dywersyfikacja dostawców gazu i systemów przesyłowych; innowacyjne projekty Sewernyj Potok (Nord Stream) i Jużnyj Potok (South Stream) Potok; kontrowersje polityczne i realność ekonomiczna; analiza retoryki medialnej na dany temat;

- Nord Stream i Jużnyj Potok (South Stream) stanowią zagrożenie dla bezpieczeństwa energetycznego Unii Europejskiej, bądź są strategicznie ważnymi projektami, zapewniającymi stałe i bezpieczne dostawy gazu ziemnego do państw unijnych? Ochrona środowiska i rurociagi Nord Stream i South Stream. Współpraca gospodarcza firm europejskich i rosyjskich w realizacji powyższych projektów.

Słowa kluczowe: Gaz ziemny, Nord Stream, South Stream, Rosja, Unia Europejska, innowacyjność, ekologia, bezpieczeństwo energetyczne, Unia Europejska 